\title{
The matrix reloaded: Reconstructing the boundaries between (international) law and politics
}

\author{
Filipe dos Reis $^{1}$ (D) and Janis Grzybowski ${ }^{2 *}$ (D) \\ ${ }^{1}$ Department of International Relations and International Organization, University of Groningen, Oude Kijk in ' $t$ Jatstraat 26, \\ 9712 EK, Groningen, The Netherlands, Email: f.r.dos.reis@rug.nl and 2European School of Political and Social Sciences, Lille \\ Catholic University, 60 Boulevard Vauban, 59800 Lille, France, Email: janis.grzybowski@univ-catholille.fr
}

\begin{abstract}
Interdisciplinary scholarship at the intersection of international law (IL) and International Relations (IR) has illuminated the roles of politics in law, of law in politics, and of the shifting boundary between the two in various areas of international affairs. The boundary itself, however, has proven resilient. While critical approaches investigating the politics of international law have come to insist on the lasting significance of legality proper, IR approaches to legalization have returned to politics. Although the apparent limits to challenging the boundary between legality and politics are not new, we suggest that they are intimately related to another great divide, i.e., that between the state and the international. Together, these two cross-cutting lines have shaped the possibilities and constraints of articulating substantive positions 'in' (international) law and politics at least since the Interwar period. Reading these distinctions as intertwined 'nested oppositions', this article reconstructs the stylized but paradigmatic debates between Max Weber and Hans Kelsen over the nature of the state and between Hans Morgenthau and Hersch Lauterpacht over the nature of the international. We further illustrate how the same conceptual oppositions still enable and constrain current debates in IL and IR, discussing as examples the creation of states and the justiciability of international crimes. Crossing and contesting the boundaries ultimately reaffirms them as the matrix in which conflicts over states and the international are articulated as legal and political.
\end{abstract}

Keywords: conceptual history; interdisciplinary boundaries; justiciability; law and politics; state creation

\section{Introduction}

As is widely acknowledged, IL and IR make for a rather complicated couple, with their 'tainted love' alternating between phases of attraction and rejection. ${ }^{1}$ While liberal IR scholars in the 1990s and 2000s studied 'legalization' (and 'judicialization') as a feature of global governance beyond

\footnotetext{
${ }^{*}$ An earlier version of this article has been presented at the international law section of the 2019 Pan-European Conference of the European International Studies Association. We would like to thank the section chairs Sofia Stolk and Renske Vos, the discussant Nikolas Rajkovic, and the participants for feedback. We would also like to thank the editors and the two anonymous reviewers for their helpful comments and suggestions. All errors and omissions are our own. The authors of this article are listed alphabetically and have contributed equally.

${ }^{1}$ A. Leander and W. Werner, 'Tainted Love: The Struggle over Legality in International Relations and International Law', in N. M. Rajkovic, T. Aalberts and T. Gammeltoft-Hansen (eds.), The Power of Legality: Practices of International Law and Their Politics (2016), 75.

(C) The Author(s), 2021. Published by Cambridge University Press. This is an Open Access article, distributed under the terms of the Creative Commons Attribution-NonCommercial-ShareAlike licence (http://creativecommons.org/licenses/by-nc-sa/4.0/), which permits noncommercial re-use, distribution, and reproduction in any medium, provided the same Creative Commons licence is included and the original work is properly cited. The written permission of Cambridge University Press must be obtained for commercial re-use.
} 
realist power politics, ${ }^{2}$ critical IL scholars endorsed 'politics' as the real game behind the formalized circuits of legal arguments. ${ }^{3}$ Or so it seemed. As Leander and Werner suggest, the boundaries have been recently re-drawn from both sides, affirming separate disciplinary identities anew. ${ }^{4}$ Indeed, while critical IL scholars have come to warn of the dangers of interdisciplinary research and the detrimental influence of IR, ${ }^{5}$ the former IR champions of 'legalization' have embarked on a search for the space left for politics in legitimizing an otherwise technical legalization. ${ }^{6}$ Explorations across disciplinary boundaries seem to have come full circle. For advocates of an interdisciplinary research agenda, the re-imposition of disciplinary boundaries risks to 'conservatively repeat and reinstate well-established scripts about politics and law', whereas it is only 'at the interstices of international relations and international law' that 'the struggle over legality ... can best be re-enacted and therefore also transformed'?

Such hopes and frustrations about interdisciplinary relations are not new, to be sure. In fact, the history of IL as a discipline, from the New Haven School through Marxism to legal pluralism and global governance and law, is marked by encounters with 'politics' ${ }^{8}$ Conversely, different shades of liberal, institutionalist, and constructivist IR approaches routinely '(re-)discovered' international law as an important field to engage with. ${ }^{9}$ Thus, perhaps we 'have been here before', ${ }^{10}$ as Koskenniemi puts it when comparing interdisciplinary dead ends today to the Interwar period. If so, however, how can we account for the resilience of the boundary between law and politics despite its fluidity and, conversely, for the repeated failure of attempts to neatly separate legality and politics, in both research and everyday practice?

This is a question not so much for the two disciplines, as about them, as well as about the practices of law and politics they seek to grasp, explore, and order. More particularly, we suggest, it is a question about the conceptual relationship between law and politics, their constitutive opposition and interdependence. As 'basic concepts', ${ }^{11}$ legality and politics are as foundational to the modern disciplines of law and political science as their relationship is ambiguous within these fields. However, we argue that they are also conditioned and constrained by their intimate connection with another great divide, i.e., that between 'the state' and 'the international', with the

${ }^{2}$ K. W. Abbott et al., 'The Concept of Legalization', (2000) 54 International Organization 401; K. J. Alter, E. M. HafnerBurton and L. R. Helfer, 'Theorizing the Judicialization of International Relations', (2019) 63 International Studies Quarterly 44; M. Finnemore and S. J. Toope, 'Alternatives to "Legalization”: Richer Views of Law and Politics', (2001) 55 International Organization 743; M. Zürn, M. Binder and M. Ecker-Ehrhardt, 'International Authority and Its Politicization', (2012) 4 International Theory 69.

${ }^{3}$ D. Kennedy, International Legal Structures (1987); M. Koskenniemi, From Apology to Utopia: The Structure of International Legal Argument (2005).

${ }^{4}$ See Leander and Werner, supra note 1.

${ }^{5} J$. Klabbers, 'Counter-Disciplinarity', (2010) 4 International Political Sociology 308; M. Koskenniemi, 'Law, Teleology and International Relations: An Essay in Counterdisciplinarity', (2012) 26 International Relations 3. For further discussion and criticism see N. M. Rajkovic, 'The Space between Us: Law, Teleology and the New Orientalism of Counterdisciplinarity', in W. Werner, M. de Hoon and A. Galan (eds.), The Law of International Lawyers (2017), 167.

${ }^{6}$ Zürn, Binder and Ecker-Ehrhardt, supra note 2; for a recent empirical analysis of the return of politics ('backlash') in the judicialization literature see D. Abebe and T. Ginsburg, 'The Dejudicialization of International Politics?', (2019) 63 International Studies Quarterly 521.

${ }^{7}$ See Leander and Werner, supra note 1 , at 97-8.

${ }^{8}$ A. Bianchi, International Law Theories: An Inquiry into Different Ways of Thinking (2016); A. Orford and F. Hoffmann (eds.), The Oxford Handbook of the Theory of International Law (2016).

${ }^{9}$ J. L. Dunoff and M. A. Pollack (eds.), Interdisciplinary Perspectives on International Law and International Relations: The State of the Art (2013); N. M. Rajkovic, T. Aalberts and T. Gammeltoft-Hansen (eds.), The Power of Legality: Practices of International Law and Their Politics (2016). For different streams of constructivism and their encounters with international legal theory see F. dos Reis and O. Kessler, 'Constructivism and the Politics of International Law', in Orford and Hoffmann, ibid., at 344 .

${ }^{10}$ M. Koskenniemi, 'Carl Schmitt, Hans Morgenthau, and the Image of Law in International Relations', in M. Byers (ed.), The Role of Law in International Politics: Essays in International Relations and International Law (2000), 17.

${ }^{11}$ R. Koselleck, 'Basic Concepts in History: A Historical Dictionary of Political and Social Language in Germany', (2011) 6 Contributions to the History of Concepts 1. 
latter understood as the realm between and above states. ${ }^{12}$ In fact, as we shall discuss, disciplinary perspectives on law and politics were differentiated in debates over the nature of the state, while IR and IL became more clearly distinguished in debates over the nature of the international. It is thus crucial to move beyond studying the two already well-known divides of politics/legality and the state/international in isolation and, instead, scrutinize them together in order to shed new light on how these divides are tenaciously maintained. This matrix, we suggest, is self-referential and selfstabilizing since it enables and limits the articulation of substantive claims about statehood and international affairs as essentially political and legal, all the while reifying the boundary between the state and the international as condition of modern politics and law.

We develop our argument in four steps. In Section 2, we outline our framework for the reconstruction of the conceptual matrix in two paradigmatic debates, i.e., the debate between Max Weber and Hans Kelsen over the nature of the state, and the debate between Hans Morgenthau and Hersch Lauterpacht over the nature of the international. In Section 3, we turn to the respective attempts by Weber and Kelsen to define the state as a sociological or legal phenomenon. While the opposed views fail to ground the state either on social facts or legal validity, and indeed reveal how one depends on the other, they furnish separate disciplinary perspectives all the while reifying the state and the international as distinct realms. In Section 4, we discuss how Morgenthau and Lauterpacht sought to bring the international under the purview of politics or law, again highlighting how neither of the contrasting perspectives prevails over the other, although their very opposition presupposes and reaffirms the international as a separate sphere in which politics and legality play out differently than 'within' the state. In Section 5, we explore two areas of contemporary debate in which the distinctions between legality and politics and between the state and the international are both challenged and reaffirmed: state creation and the international justiciability of international crimes in (non-)international armed conflicts. As both examples illustrate, the boundaries between (international) law and politics are indeed constantly challenged and re-drawn in concrete instances, but within the matrix of (international) politics and law, which is thus affirmed as the very condition of possibility for any boundary stretching, blurring, and re-imposition. In the conclusion, we reflect upon the (im)possibility to transcend the matrix, as discussed in recent critical scholarship.

\section{Reconstructing a conceptual matrix of two lines}

In both IL and IR, scholars have recently paid heightened attention to the specific role of concepts in academic research as well as in everyday political and legal practice. ${ }^{13}$ As many of these interventions emphasize, taking concepts seriously means going beyond a merely instrumental understanding of more or less complex definitions serving as 'building blocks' for further assessments, a view commonly held in both (neo-)positivist social science and traditional legal approaches. ${ }^{14}$ Instead, concepts should be regarded as deep-seated presuppositions guiding practice and analysis alike by rendering experiences and statements intelligible and meaningful in the first place, but thereby also shaping how we understand the world, perceive its 'problems', and find appropriate 'solutions'. To analyse concepts in such a way also means to reconstruct the use and performative

\footnotetext{
${ }^{12}$ On the specificity of 'the international' see, for instance, R. B. J. Walker, After the Globe, before the World (2010).

${ }^{13}$ For IR see S. Guzzini, 'The Ends of International Relations Theory: Stages of Reflexivity and Modes of Theorizing', (2013) 19 European Journal of International Relations 521; F. Berenskoetter (ed.), Concepts in World Politics (2016); for IL see M. Clark, 'Ambivalence, Anxieties/Adaptations, Advances: Conceptual History and International Law', (2018) 31 LJIL 747; J. d'Aspremont and S. Singh (eds.), Concepts for International Law: Contributions to Disciplinary Thought (2019).

${ }^{14}$ See G. King, R. O. Keohane and S. Verba, Designing Social Inquiry: Scientific Inference in Qualitative Research (1994); G. Sartori, 'Concept Misformation in Comparative Politics', (1970) 64 American Political Science Review 1033. For traditional legal approaches in general see the discussion in Bianchi, supra note 8, at 21. For international legal positivism's understanding of language see I. Venzke, 'Post-Modern Perspectives on Orthodox Positivism', in J. Kammerhofer and J. d'Aspremont (eds.), International Legal Positivism in a Post-Modern World (2014), 182.
} 
effects of concepts over time, i.e., historically. This has been expressed, if in arguably different ways, by a number of scholars often invoked in the renewed calls for the (re-)turn to concepts in IR and IL, including Reinhart Koselleck, Quentin Skinner, Michel Foucault, Jacques Derrida, and Ian Hacking. ${ }^{15}$ Without pretending to embark on a full-scale discourse analysis or conceptual history of the notions of legality and politics in IR and IL, or to rigourously follow one particular approach in reconstructing these concepts, we take three major cues from these approaches for our sketch of the constitutive matrix of (international) law and politics.

First, the meanings and referents of 'basic concepts' are not sharply circumscribed, as if they were 'mirroring' a world outside of language, but contingent upon the relations with other concepts and their contexts of use. This is why attempts to define such similarly central and ambiguous notions as 'sovereignty', 'the state', 'justice', and 'equity' regularly lead to frustration, ${ }^{16}$ and why their meaning in use seems indeterminate. ${ }^{17}$ Rather than trying to define and delineate legality and politics or the state and the international, and then studying something else on that basis, we seek to reconstruct how these concepts have shaped the very articulation of substantive claims and conflicts. In other words, the differentiated legal and political notions of the state and the international are not the starting point of our inquiry, but its object.

Second, and related, we understand the distinctions between (international) law and politics as two overlapping 'nested oppositions' 18 that form a matrix. Nested oppositions involve entangled concepts that not only contradict each other in some respects, but also rely on and co-constitute each other in various other respects. ${ }^{19}$ As we shall discuss, law not only opposes but also extends, enables, and structures politics, and vice versa, so that what is legal and what political differs not only with changing contexts but also with any particular perspective. In this article, we therefore revisit debates over the legal or political nature of the state and the international not to 'settle' them, but to sketch how they have paradigmatically expressed the nested and thus instable oppositions of (international) law and politics.

Third, to the extent to which current academic debates and discourses in practice invoke or imply these interlocking oppositions, we argue that they entail a 'looping effect' that reifies the matrix, because the more we seek to come to grips with any phenomenon in terms of legality or politics, or as international or domestic, the more we enact these distinctions themselves. ${ }^{20}$ The conceptual matrix thus generates or structures the very reality we experience, so that even when we question the boundaries of (international) politics and law, we notice that 'we have been here before ${ }^{21}$ and that 'renewal repeats'. ${ }^{22}$ Our analysis thus also aims to reconstruct how the conceptual relations between (international) politics and law still shape and constrain analyses and arguments today, as we illustrate with reference to debates about state creation and the international justiciability of international crimes.

\footnotetext{
${ }^{15}$ See, for example, R. Koselleck, The Practice of Conceptual History: Timing History, Spacing Concepts (2002); Q. Skinner, Visions of Politics: Regarding Method (2002); J. Derrida, Of Grammatology (1967); M. Foucault, Archaeology of Knowledge (1969); I. Hacking, Historical Ontology (2002). For an overview of different approaches see Berenskoetter, supra note 13.

${ }^{16}$ See J. Bartelson, The Critique of the State (2001); Koskenniemi, supra note 3.

${ }^{17}$ See Kennedy, supra note 3; Koskenniemi, ibid. For an overview see C. A. Miles, 'Indeterminacy', in J. d'Aspremont and S. Singh (eds.), Concepts for International Law: Contributions to Disciplinary Thought (2019), 447.

${ }^{18}$ J. M. Balkin, 'Nested Oppositions', (1990) 99 Yale Law Journal 1669. The notion of 'nested oppositions' is mainly based on a simplified reading of Derrida's deconstruction, but Balkin also invokes Wittgenstein's notion of 'family resemblance' as an approach to nested oppositions; ibid., at 1676.

${ }^{19}$ Ibid., at 1674 .

${ }^{20}$ I. Hacking, 'The Looping Effects of Human Kinds', in D. Sperber, D. Premack and A. J. Premack (eds.), Causal Cognition: A Multi-Disciplinary Approach (1995), 351; for the analysis of looping effects of phenomena, rather than people see, e.g., J. Bartelson, War in International Thought (2018), 23.

${ }^{21}$ See Koskenniemi, supra note 10.

${ }^{22}$ D. Kennedy, 'When Renewal Repeats: Thinking Against the Box', (1999) 32 NYUJ Int'l L. \& Pol. 335. See also A. Anghie, Imperialism, Sovereignty, and the Making of International Law (2005), for the renewal of (post)colonial hierarchies throughout the history of international law.
} 
Table 1. The Matrix of (International) Law and Politics

\begin{tabular}{ccc}
\hline & Politics (power/effectiveness) & Law (validity) \\
\hline $\begin{array}{c}\text { The State } \\
\text { (the domestic) }\end{array}$ & $\begin{array}{c}\text { Power/effectiveness as essence of the } \\
\text { state (Max Weber) }\end{array}$ & $\begin{array}{c}\text { Legal validity as essence of the state } \\
\text { (Hans Kelsen) }\end{array}$ \\
$\begin{array}{c}\text { The International } \\
\text { T. Power/effectiveness as essence of the } \\
\text { international (Hans Morgenthau) }\end{array}$ & $\begin{array}{c}\text { Legal validity as essence of the international } \\
\text { (Hersch Lauterpacht) }\end{array}$ \\
\hline
\end{tabular}

Following these insights into the role and analysis of 'basic concepts' as 'nested oppositions', we aim to sketch the matrix of four fields by reconstructing two stylized but paradigmatic confrontations over the nature of the state and the international. We locate these 'debates' in the Interwar period, taking our cue from the often-reiterated view that 'despite substantial common interests, international law and international relations, and their parent disciplines of law and political science, diverged and became largely estranged after the shock of the Second World War'. ${ }^{23}$ We do not, however, adopt a rigid periodization, nor are we interested in any 'origins' of the distinctions between law and politics or between the state and the international; rather, we are interested in how these distinctions, which are indeed older, were tightly interwoven and thus became constitutive for the respective disciplines. ${ }^{24}$ Weber, Kelsen, Morgenthau, and Lauterpacht achieved canonical status and are routinely invoked as authorities in their respective fields precisely because they sought to ground the state and the international in legality and politics, respectively, thus providing the conceptual basis for all further inquiries in IR and IL. Even though in their own work all four of them moved from one corner to another with relative ease, they all took distinct positions on the essence of the state or the international that appear, at least retroactively, as paradigmatic (see Table 1).

We thereby follow scholarship in IR and IL that has problematized the boundaries of the modern international, emphasizing the productive force of blind spots and paradoxes within and between disciplines, and that has explored the silences, 'bounds of sense', and respective 'horizons' of international legal and political argumentation. ${ }^{25}$

This exercise in conceptual reconstruction comes with necessary qualifications. First, we locate the articulation of boundaries between law and politics within interdisciplinary debates, thus following the call of Andrew Abbott to focus on interprofessional competition, rather than recounting the 'internal' (de-)professionalization of particular disciplines. ${ }^{26}$ This imposes limits on the attention we can pay to other disciplinary discussions. Second, in associating the four scholars with opposed positions in distinct corners, we deliberately simplify to sharpen the view for the basic 'nested oppositions'. Although we, thus, cannot do justice to the complexity of their respective intellectual trajectories, we do show how the position of any particular corner is inherently instable and acknowledge that there were important moves from one field to another, such as Kelsen's

\footnotetext{
${ }^{23}$ M. A. Pollack, 'Is International Relations Corrosive of International Law: A Reply to M. Koskenniemi', (2013) 27 Temple International and Comparative Law Journal 339, at 339. See also M. Koskenniemi, The Gentle Civilizer of Nations: The Rise and Fall of International Law, 1870-1960 (2001), Ch. 6.

${ }^{24}$ Periodizations, such as Interwar or Cold War, are not neutral facts but 'interpretations of facts'. Importantly, '[e]very periodization is inherently problematic as any period is an abstraction from the historical fact', O. Diggelmann, 'The Periodization of International Law', in B. Fassbender and A. Peters (eds.), The Oxford Handbook of the History of International Law (2012), 997, at 999, 1003; for a critique of Eurocentric periodization in IL and IR see, respectively, J. d'Aspremont, 'Turntablism in the History of International Law', (2020) 22 Journal of the History of International Law/ Revue d'histoire du droit international 472; T. Barkawi, 'Decolonising War', (2016) 1 European Journal of International Security 199.

${ }^{25}$ Some foundational texts include Kennedy, supra note 3; Koskenniemi, supra note 3; F. V. Kratochwil, Rules, Norms, and Decisions: On the Conditions of Practical and Legal Reasoning in International Relations and Domestic Affairs (1989); N. G. Onuf, World of Our Making: Rules and Rule in Social Theory and International Relations (1989).

${ }^{26}$ A. Abbott, The System of Professions: An Essay on the Division of Expert Labor (1988).
} 
increasing appeal to the international to anchor the legality of the state or Morgenthau's growing confidence in the state and diplomacy to tame international power politics. Third, we do not trace the emergence, diffusion, and significance of these fundamental conceptual oppositions in any comprehensive way, which would go beyond the scope of this article. ${ }^{27}$ In particular, we do not tell an 'origins' story but see the Interwar period as an important focal point to sketch the articulation of (international) law and politics in their fundamental conceptual oppositions that, as we illustrate by way of examples in Section 5, structurally link and separate these fields until today. ${ }^{28}$ Fourth, as a part of an interdisciplinary canon, the oppositions articulated by Weber, Kelsen, Morgenthau, and Lauterpacht have ensured connectivity, compatibility, and accessibility, but they at the same time excluded alternatives and (re)produced established hierarchies. ${ }^{29}$ Rather than exploring such alternatives, we scrutinize the emergence of the matrix and reconstruct how the canon is actively, but not necessarily intentionally, reproduced in scholarship and international legal practice. However, as we discuss in the conclusion, a critical understanding of the politics of canon formation is also essential to appreciate the possibilities, as well as the limits, of potential alternatives.

\section{Weber, Kelsen, and the state between sociology and law}

While both IL and IR are committed to the notion that states are the building blocks of the international system, opinions within and across the two disciplines diverge on whether states are ultimately a matter of fact or of law, and identified by sociological or legal methods. In this section, we reconstruct the division between the sociological and the legal understanding of the state in the influential attempts by Max Weber and Hans Kelsen to overcome a unified and - they both agreed - 'metaphysical' notion of the state by developing rigorous disciplinary approaches to disclose its true nature. As we suggest, however, Weber and Kelsen ultimately had to base their legal and sociological concepts of the state on the respective other concept, thus fundamentally entangling them. By pushing reductions of the state to either empirical effectiveness or legal validity to the extreme, they nevertheless defined the boundaries and typical circuits of arguments about the political or legal nature of the state. Unable to solve the question at the 'domestic' level, Kelsen ultimately appealed to the international, as the sphere where law could be anchored, thus also setting the stage for the debate over the nature of the international by Morgenthau and Lauterpacht.

The functional differentiation of disciplinary perspectives on the state has arguably a long and complex history that begins well before Weber and Kelsen came to think about the state in their respective disciplinary terms. ${ }^{30}$ Within the German-speaking context alone, the juridical perspective on the state had become increasingly autonomous already in the work of Carl Friedrich Gerber and Paul Laband, although it remained tied to preceding notions of the nation or the state as unified will, person, or organism. ${ }^{31}$ Georg Jellinek's Allgemeine Staatslehre is the, perhaps, last great attempt to provide an encompassing synthesis of all dimensions of the state, although he precisely distinguished the legal and the sociological dimensions as its two sides, leading critics

\footnotetext{
${ }^{27}$ For such wider sketches of disciplinary histories see, for example, Koskenniemi, supra note 23; B. C. Schmidt, The Political Discourse of Anarchy: A Disciplinary History of International Relations (1998).

${ }^{28}$ For a critique of the search for monocausal 'origins' stories see E. W. Said, Beginnings: Intention and Method (1975); see also P. Bilgin, 'On the "Does Theory Travel?” Question: Traveling with Edward Said', in Z. G. Çapan, F. dos Reis and M. Grasten (eds.), The Politics of Translation in International Relations (2021), 245.

${ }^{29}$ See, for example, W. D. Mignolo, 'Canons A(nd)Cross-Cultural Boundaries (Or Whose Canon Are We Talking About)', (1991) 12 Poetics Today 1.

${ }^{30} \mathrm{M}$. Stolleis, Geschichte des Öffentlichen Rechts in Deutschland. Band 2. Staatsrechtslehre und Verwaltungswissenschaft, 1800-1914 (1992). See also Bartelson, supra note 16.

${ }^{31}$ See Stolleis, supra note 30, at 330-80; see also A. Koschorke et al., Der fiktive Staat: Konstruktionen des politischen Körpers in der Geschichte Europas (2007), 338-76.
} 
to argue that he could not plausibly reunite them. ${ }^{32}$ Indeed, soon thereafter the attempt to reconcile philosophical idealism, historiography, natural law, positivism, and emerging sociology and psychology in a single account of the state appeared to be thoroughly anachronistic, as dealing with 'a mass of problems ... thrown together under the somewhat vague description of Staatslehre. ${ }^{33}$ Instead of assuming the state as the starting point of their inquiries, the new advocates of properly disciplinary approaches sought to ground the state in their respective spheres of study, assuming the primacy of sociological facts or legal norms of which the state was but an expression. Weber's sociological and Kelsen's 'purely' legal perspectives illustrate this paradigmatically, and both had a lasting impact on conceptualizations of the state also in IR and IL.

\subsection{Weber: The sociological reduction of the state}

In his Economy and Society, ${ }^{34}$ Weber famously begins his inquiry with a set of definitions, including of power, domination, legitimacy - and the state. In contrast to his fine-grained analysis of actual forms of political domination emerging and transforming in history discussed in the main parts of the book, Weber's concepts, including that of the modern state, are elegantly simplistic. As an ideal type, the concept of the state was to be freed from its legal and philosophical roots and opened up to 'scientific' sociological inquiry. To Weber, sociology differs as an 'empirical science of behaviour' from 'dogmatic' sciences, among which he counts law, in that it does not seek to establish, and indeed excludes, 'metaphysical' meaning. ${ }^{35}$ As such, as Weber already explained in his lecture on Politics as a Vocation, the state cannot be defined by its 'purposes' but only by its specific 'means'. ${ }^{36}$ The normative is thus shut out so as to rigorously approach the state as an empirical phenomenon, rather than presupposing it as a vague metaphysical entity. Although the passage is well-known, it is worthwhile quoting it at length here:

... in the final analysis the modern state can be defined only sociologically by the specific means that are peculiar to it, as to every political organization: namely, physical violence ... Violence is, of course, not the normal or the only means available to the state ... But it is the means specific to the state ... [T] he state is the form of human community that (successfully) lays claim to the monopoly of legitimate physical violence within a particular territory and this idea of 'territory' is an essential defining feature ... [W] hat "politics" means for us is to strive for a share of power or to influence the distribution of power, whether between states or between the groups of people contained within a state. ${ }^{37}$

This set of definitions illustrates the close conceptual connections between statehood, politics, power, and violence, between community, territory, and authority. Politics are tightly packaged, they take place within or between states which emerge as largely pacified and delineated spaces of order, 'bordered power-containers' as Giddens would later put it. ${ }^{38}$ Historically, Weber explains,

[t]he modern state begins to develop wherever the monarch sets in train the process of dispossessing the autonomous, "private" agents of administrative power who exist in parallel to

\footnotetext{
${ }^{32}$ G. Jellinek, Allgemeine Staatslehre (1928 [1900]). See also E. Voegelin, 'Kelsen's pure theory of law', (1927) 42 Political Science Quarterly 268; Koskenniemi, supra note 23, at 198-208; M. García-Salmones Rovira, The Project of Positivism in International Law (2013), 181-3.

${ }^{33}$ See Voegelin, ibid., at 269. See more generally Stolleis, supra note 30, at 447-59; Koskenniemi, supra note 23, at 177-83.

${ }^{34} \mathrm{M}$. Weber, Economy and Society: A New Translation (2019).

${ }^{35}$ Ibid., at 4.

${ }^{36}$ M. Weber, The Vocation Lectures (2004), 33.

${ }^{37}$ Ibid.

${ }^{38}$ A. Giddens, The Nation-State and Violence: Volume Two of a Contemporary Critique of Historical Materialism (1985), 120
} 
... [the state], that is to say, all the independent owners of the materials of war and the administration, financial resources, and politically useful goods of every kind. ${ }^{39}$

In this conceptual framework, the state is domestically structured by an 'organization' or a 'ruling apparatus that calls for continued administration' which 'should have at ... [its] disposal the material resources necessary to make use of physical force'. ${ }^{40}$ In tracing state formation from the perspective of this ideal-typical endpoint and benchmark, the Weberian state concept acquired a 'double status as both empirical and transcendental'. ${ }^{41}$ While the space within which state formation took place was analytically presupposed, the politics within and between states were subjected to the empirical analysis of bounded historical change.

The long-term impact of this notion of the state on sociology, political science, and IR can hardly be overestimated. Major works of state formation have been influenced by Weber's understanding of it - although alongside others, such as Marx's - and notably by his emphasis on the acquisition of the coercive and fiscal means of power, processes of bureaucratization, and the establishment of effective territorial rule. ${ }^{42}$ Despite various attempts to escape, widen, or complement the Weberian state concept in the past 100 years, it casts a long shadow on our notions of the 'modern' state and politics. ${ }^{43}$

Indeed, while the IR realist notion of the international system as characterized by the eternally repeating dynamics of power politics has a long pedigree in political thought, Weber has been assigned a particular place in it. ${ }^{44}$ Modernity had disenchanted the world and imposed its 'iron cage $^{35}$ of instrumental reason, but 'within' and 'between' states there was politics, ${ }^{46}$ and thus contingency, if within the limits of this particular spatio-temporal order. ${ }^{47}$ Although it also invites for reflections about an ethics of responsibility and prudent statesmanship, 'politics' is ultimately about struggles for 'power', and absent any universally valid truths or ethics, the struggle for power between states is hardwired into the modern international itself. Thus, for Walker, ' $t$ ] he analysis of ethics and international relations ... returns, with Weber, to a radical scepticism in which geopolitics meets nihilism in the glorification of the state'. ${ }^{48}$ As we discuss below, Morgenthau's conceptualization of international politics continued this line of thought, as would much of 'realist' IR theory. ${ }^{49}$

Back in the 1920s, Weber's influential reduction of the state to a successful claim to a monopoly of legitimate physical violence led a prominent critic in the neighbouring discipline of law to argue that Weber's notion was actually based on a juridical concept of the state, despite all rhetoric of a genuine sociological view. This prominent critic was Hans Kelsen.

\subsection{Kelsen: The state as legal order - and the turn to international law}

In a wide-sweeping analysis of prevailing sociological and juridical notions of the state, Kelsen maintained that, by postulating that the state would hold the monopoly of violence, Weber

\footnotetext{
${ }^{39}$ See Weber, supra note 36 , at 37.

${ }^{40}$ Ibid., at 35 .

${ }^{41}$ See Bartelson, supra note 16 , at 34.

${ }^{42}$ See, for instance, Giddens, supra note 38; M. Mann, The Sources of Social Power, vol. I, II, III, IV (2012); C. Tilly, Coercion, Capital, and European States, AD 990-1992 (1992). For an overview see T. Vu, 'Studying the State through State Formation', (2010) 62 World Politics 148.

${ }^{43} \mathrm{See} \mathrm{Vu}$, ibid. On failed attempts to overcome the state concept see also Bartelson, supra note 16.

${ }^{44}$ R. B. J. Walker, Inside/Outside: International Relations as Political Theory (1993).

${ }^{45} \mathrm{M}$. Weber, The Protestant Ethic and the Spirit of Capitalism (1930), 123.

${ }^{46}$ Weber, supra note 36 , at 33.

${ }^{47}$ K. Palonen, Das 'Webersche Moment': Zur Kontingenz des Politischen (1998); Walker, supra note 44, at 72.

${ }^{48}$ See Walker, ibid.

${ }^{49}$ Cf. T. Barkawi, 'Strategy as a Vocation: Weber, Morgenthau and Modern Strategic Studies', (1998) 24 Review of International Studies 159.
} 
had essentially employed a normative or legal concept of order because a monopoly could never exist empirically, as material reality. ${ }^{50}$ To Kelsen, much like Weber, the most important difference between sociology and law as disciplines was that sociologists were interested in empirical facts whereas lawyers thought in terms of legal validity. However, in his view, it was impossible to reduce the state sociologically because the state as a frame of reference, as a unity, was per definition normative and thus juridical. ${ }^{51}$ For Kelsen, only Weber's ideal-types actually ordered social reality and invested empirical behaviour with meaning; and these ideal-types preceded the empirical analysis. ${ }^{52}$

This is illustrated, for instance, by the revolutionary overhaul of a state's constitution. The same empirical events can be either seen as founding act of a new constitutional order or as high treason against the old one. To Kelsen, the real difference between the former and the latter depends on which 'basic norm' (Grundnorm) is presupposed. ${ }^{53}$ The legitimacy of the 'state' does not derive from its factual power but from the presupposition that any norms and rules within it are valid because they are subject to the system's Grundnorm. In this sense, the Grundnorm is a 'transcendental-logical presupposition'. ${ }^{54}$ Kelsen thus contends that the sociological concept of the state was essentially dependent on a normative concept to give the empirical features of the state their coherent form, locality, and significance. ${ }^{55}$

Accordingly, for Kelsen, the state criteria of government, population, and territory can only be juridical concepts because in sociological terms there is no complete cohesion of a people, no natural homogeneity of a territory, and no proper monopoly over the legitimate use of force.$^{56}$ Force is no independent sub-category of statehood because it is already implied by the normative understanding of the state. ${ }^{57}$ All concepts of the state that regard the state as distinct from law, i.e., as a material correlate to the ideational character of the law, commit to an illusion because the state is nothing but the law: ${ }^{58}$

The "power" of the state can show itself only in the specific means of power which are at the disposal of a government; in the fortresses and prisons, the guns and gallows, the individuals uniformed as policemen or soldiers. But these fortresses and prisons, these guns and gallows, are dead objects; they become tools of state power only so far as they are used by a state government or by individuals according to orders directed to them by the government, only so far as the policemen and soldiers obey the norms that regulate their behavior. The power of the state is no mystical force concealed behind the state or its law; it is only the effectiveness of the national legal order. ${ }^{59}$

For Kelsen, Weber actually fell back on metaphysics - unless the identity of the state which he presupposed in his sociological reduction was understood legally, i.e., as emanating from a normative order composed of internal legal references.

Having died before this critique was published, Weber had no opportunity to respond. The critique by Kelsen can be reversed from the sociological viewpoint, however. If the validity of any legal order depends itself in the last instance on the validity of a Grundnorm, there is no legally

\footnotetext{
${ }^{50}$ H. Kelsen, Der Soziologische und der Juristische Staatsbegriff (1928), 170.

${ }^{51}$ Ibid., at $8-9$.

${ }^{52}$ Ibid., at 4-11, 156-70. This does not mean that Kelsen did not have a sociological concept of social reality of his own, which in turn influenced his view on legality; see García-Salmones Rovira, supra note 32.

${ }^{53} \mathrm{H}$. Kelsen, Pure Theory of Law (2005), 205-14.

${ }^{54}$ Ibid., at 201. See also S. L. Paulson, 'Kelsen's Legal Theory: The Final Round', (1992) 12 Oxford Journal of Legal Studies 265.

${ }^{55}$ See Kelsen, supra note 50 , at 75, 82, 92.

${ }^{56}$ Ibid., at $4-19$.

${ }^{57}$ Ibid., at 82 .

${ }^{58}$ See Kelsen, supra note 53, at 318-20.

${ }^{59}$ Ibid., at 290.
} 
compelling reason to accept one or another basic legal norm - and in case of conflict, there would be no impartial position from which to judge which one was actually 'in force'. Kelsen's assumption that factual power would necessarily be identical with legal normativity is, as his contemporary Hermann Heller acidly put it, a 'logically incomprehensible answer' ${ }^{60}$ More specifically, it is ultimately unclear whether Kelsen's notion of a coherent legal order is anchored in an ideal hypothesis in neo-Kantian fashion or in a state of reality that enters the analysis externally. If it is merely an ideal hypothesis independent of the phenomenon it describes, then it appears indeed that ' $\mathrm{t}$ ] he problems of the pure theory do not lie in its internal coherence but in its relationship to the surrounding world' ${ }^{61}$

If, on the other hand, social reality does enter as a criterion for identifying the proper basic norm, then Kelsen's approach takes a radical turn because he invokes effectiveness as the decisive criterion and, thereby, as ultimate ground for any concrete state. As he contends:

if ... [a] relatively centralized coercive order, subordinated only to international law, is by and large effective ... the community constituted by such a coercive order is a "state" ... [a] valid legal order in the sense of international law. ${ }^{62}$

A state - or national legal order - is effective if the norms created in conformity with it are by and large applied and obeyed'. ${ }^{63}$ Thus, behind the legal order lurks power as 'effectiveness'. ${ }^{64}$ This appears to be a concession to Weber. Legal scholars who read Kelsen in this way have remarked that it seems 'indeed paradoxical' that the 'perhaps ... most influential normative theory that was ever launched ... rests on the "principle" of effectiveness' ${ }^{65}$ It would appear that Weber's sociological state concept returns by the back door.

However, Kelsen maintains that it is not effectiveness as such which makes states, but its status as legal principle under international law:

A norm of general international law authorizes an individual or a group of individuals, on the basis of an effective constitution, to create and apply as a legitimate government a normative coercive order. That norm, thus, legitimizes this coercive order ... as a "state" in the sense of international law - regardless of whether the government came to power in a "legitimate" way $\ldots$ or by revolution. ${ }^{66}$

Although states are thus defined by the effectiveness of their 'internal' legal order, ${ }^{67}$ this is so only because it is a norm of international law, presuming the primacy of international law above states. ${ }^{68}$ Moreover, since facts do not speak for themselves, they become only legally relevant upon interpretation. In the 'primitive' and 'decentralized' international legal order, its organs are the existing states and their legal recognition thus constitutes new states for the purposes of

\footnotetext{
${ }^{60}$ H. Heller, Die Souveränität. Ein Beitrag zur Theorie des Staats- und Völkerrechts (1927), 53.

${ }^{61}$ See Koskenniemi, supra note 3, at 249.

${ }^{62}$ See Kelsen, supra note 53, at 337 (emphasis added).

${ }^{63} \mathrm{Ibid}$., at 210; see also Kelsen, supra note 50, at 98-9; Kelsen, supra note 53, at 208-14; G. Kreijen, State Failure, Sovereignty, and Effectiveness (2004), 211-30.

${ }^{64}$ See Kelsen, supra note 53, at 290, 214-16. As Voegelin notices, 'at this point the theory of state sovereignty clashes with the problems of international law' (supra note 32, at 273), more specifically with the problem of recognition of individual states in international law as the necessarily prior legal order.

${ }^{65}$ See Kreijen, supra note 63, at 212.

${ }^{66}$ See Kelsen, supra note 53, at 215. See also H. Kelsen, Das Problem der Souveränität und die Theorie des Völkerrechts (1920), 224-41.

${ }^{67}$ H. Kelsen, 'Recognition in International Law. Theoretical Observations', (1941) 35 AJIL 605, at 608.

${ }^{68}$ See Kelsen, supra note 66. See also J. von Bernstorff, The Public International Law Theory of Hans Kelsen: Believing in Universal Law (2015).
} 
international law. ${ }^{69}$ While acknowledging the relevance of the sociological notion of the state for establishing the effectiveness of states, Kelsen thus ultimately preserves his view on the primacy of law by anchoring it in the international realm. Here, after all, one can ostensibly assume an encompassing and sufficiently coherent legal order which designates individual states by recognition, understood as properly legal 'co-gnition'. ${ }^{70}$

Alas, in attempting to banish the spectre of state sovereignty domestically, Kelsen ultimately invites it back in through the international. ${ }^{71}$ Although he maintains that there is a difference between mere 'political' and proper 'legal recognition', and that only the latter actually establishes states, critics have found his attempt to have it both ways implausible. ${ }^{72}$ For all intents and purposes, Kelsen ultimately accepts the constitutive doctrine of recognition, according to which states achieve international status only upon recognition, rather than by virtue of having achieved a particular degree of factual effectiveness on the ground. ${ }^{73}$ Yet this essentially leaves it to existing states to decide whether or not new states had emerged, and - absent any oversight over their interpretation of the facts - to international politics. ${ }^{74}$

Kelsen's student Lauterpacht would try to move beyond the apparent limits of positive law, argue for a 'duty to recognize ${ }^{75}$ new states, and hope for the 'collectivization of the process of recognition ${ }^{176}$ by an organized international community. The alternative was that states were either evident facts after all or else determined by Weber's 'politics between states' that Morgenthau would argue was the essence of the international at any rate.

The reconstruction of Weber's sociological and Kelsen's legal concept of the state paradigmatically illustrates not only their differences but also their co-constitution, since the sociological notion is revealed to depend on the legal one, and vice versa. This nested opposition renders substantive arguments about the legal or political nature of states inherently instable and flexible, as we shall discuss further below. Moreover, the despised 'metaphysics' of the state remains firmly in place, since 'the state' is neither reduced to legal validity nor to effective power. The assumption that there are states at all is meanwhile reinforced by what both Weber and Kelsen assume is the counterpart of individual states, i.e., the international composed of a multiplicity of states. Thus, while the entangled distinction between a legal and a political view of the state amplifies the difficulty to identify individual states, the need to identify individual states as part of the international animates debates over their legal or political nature in the first place. Whether law could at all be anchored in the international realm, as Kelsen hoped, or would encounter power politics yet again, as Weber thought, would be the bone of contention in another paradigmatic debate.

\section{Morgenthau, Lauterpacht, and the international between politics and law}

Although both IR and IL specifically engage with the international realm, they are traditionally anchored in opposite views of its 'true' nature. In this section, we reconstruct this nested opposition by revisiting the diverging positions of Hans Morgenthau and Hersch Lauterpacht in the

\footnotetext{
${ }^{69}$ See Kelsen, supra note 67, at 607.

${ }^{70}$ Ibid., at 606.

${ }^{71}$ H. Kelsen, 'Sovereignty and International Law', (1960) 48 Georgetown Law Journal 627.

${ }^{72}$ See J. Crawford, The Creation of States in International Law (2006), 21; T.-C. Chen, The International Law of Recognition. With Special Reference to Practice in Great Britain and the United States (1951), 47.

${ }^{73}$ For instance, Chen argues that with this argument 'Kelsen abandons his former declaratory view and declares himself in favour of the constitutive theory' of recognition; Chen, ibid., at 41.

${ }^{74}$ See Kelsen, supra note 67 , at 606.

${ }^{75} \mathrm{H}$. Lauterpacht, Recognition in International Law (1947), at 7-12, 73; for a critical discussion by another Kelsen student who upheld the restriction to 'positive international law' see J. L. Kunz, 'Critical Remarks on Lauterpacht's "Recognition in International Law"', (1950) 44 AJIL 713.

${ }^{76}$ See Lauterpacht, ibid., at 67-8.
} 
debate over the doctrine of the (non)justiciability of international disputes. Marginal though it might seem, this debate has not only a long history from Vattel to the Kellogg-Briand Pact, ${ }^{77}$ but it also represents an important focal point in the separation of IR and IL as it centres around the question of whether the international is ultimately a realm of politics, in which law only plays a minor role, or instead an essentially legal order able to tame power politics. While Morgenthau came to argue that vital conflicts on the international level were political and thus non-justiciable, Lauterpacht maintained that all conflicts were in principle justiciable and that it was precisely the judicial function to find the applicable (international) law, and thereby also constitute an international community based on law. The boundary between law and politics is in flux, however. Lauterpacht's proactive stance on the development of international law could also be construed as a political project in its own right, while Morgenthau's insistence on the role of state diplomacy seems to sustain a traditionally restricted notion of international law as law between states. Moreover, in delineating seemingly opposed views on the international, both Morgenthau and Lauterpacht also presume and reaffirm individual states as correlate of the international, invoking them either as political powers or domestic realms of law.

\subsection{Morgenthau: The limits of international law}

Looking back in 1974 to influences on the formation of his approach to international law, Morgenthau considers that it was the debate on the non-justiciability of international disputes that profoundly shaped his thought and set the foundation for his general scepticism concerning the effectiveness of international law. ${ }^{78}$ More precisely, it was in his doctoral dissertation in law, which he completed in 1927 and published as a revised version two years later as Die internationale Rechtspflege, ihr Wesen und ihre Grenzen [The International Judiciary, its Nature and its Limits], where Morgenthau first developed the outline of his image of the relationship between international law and politics. ${ }^{79}$ The thesis examines the question of whether states feel obliged to subordinate their conflicts to organs of the international judiciary (meaning bodies of arbitration or courts) and, if they do so, to what extent this is the case. The topic of the thesis was, as Koskenniemi notes, 'a rather standard object of scholarly interest in the $1920 \mathrm{~s}$ ' ${ }^{80}$ Morgenthau was mainly puzzled by the fact that, on the one hand, the scope of the international judiciary is - in 'objective' terms - unlimited as every international conflict can be subsumed under general norms while, on the other hand, in reality not all international conflicts are addressed before the international judiciary. ${ }^{81}$ Morgenthau explains this gap by arguing that the 'subjective' limits of the political determine how law and politics are related. As he famously remarks:

The concept of the "legal" and the "political" do not constitute an adequate pair of concepts that could enter into a contradictory distinction. The conceptual distinction of the concept of political questions is formed by the concept of non-political questions and not by the concept of legal questions which, for its part, can be just as much of political as of non-political nature. ${ }^{82}$

As law and politics are not conceptualized as directly opposed, we can distinguish political conflicts or, as Morgenthau calls them, tensions (Spannungen), from non-political conflicts, in Morgenthau's words, differences (Streitigkeiten). While differences can be tamed by delegating

\footnotetext{
${ }^{77}$ A. Nussbaum, A Concise History of the Law of Nations (1947), Ch. 6; O. Jütersonke, Morgenthau, Law and Realism (2010), $45-7$.

${ }^{78}$ H. J. Morgenthau, 'International Law and International Politics: An Uneasy Partnership', (1974) 68 Proceedings of the Annual ASIL Meeting 323, at 332.

${ }^{79}$ H. J. Morgenthau, Die internationale Rechtspflege, ihr Wesen und ihre Grenzen (1929).

${ }^{80}$ See Koskenniemi, supra note 23 , at 440.

${ }^{81}$ See Morgenthau, supra note 79 , at 42.

${ }^{82}$ Ibid., at 79 .
} 
them to the various mechanisms of the international judiciary, tensions cannot be legally resolved. As a 'particularity of international relations' ['Eigentümlichkeit der zwischenstaatlichen Beziehungen'], tensions emerge from states' vital interests and concern for their national honour, and can thus only be addressed by political means. ${ }^{83}$

Yet, it is not possible to decide a priori whether a conflict in the international sphere is political or not. There are no objective criteria, which would allow us to consider a conflict as either political or non-political. ${ }^{84}$ Rather, the question of whether something is political or not depends on the subjective perception of states themselves. Moreover, this observation, which should also become the main topic of his second monograph on The Concept of the Political (published in 1933), has important consequences, as the:

distinction between political and non-political questions with regard to certain purposes is impossible as the concept of the political ... has no substance, which is once and for all fixed, because it is rather a feature, a quality, a colouring, which can be attached to any kind of substance. $^{85}$

Whether an issue or conflict becomes political is in the end a question of its 'intensity'. ${ }^{86}$

According to Morgenthau, these insights about the 'indeterminate, through judicio-technical fixation untameable concept of the political' should help to create a more effective international legal order. ${ }^{87}$ Such an order should consist of two features: firstly, it should be aware of its own (subjective) limitations and, secondly, it should be dynamic rather than static (as, e.g., in legal formalism) in order to be able to adapt quickly enough to the untameable nature of politics. ${ }^{88}$ Thus, while Morgenthau regards international law as dominated by international politics, his international politics is rather close to a traditional, 'non-utopian' understanding of international law itself. In this context law mainly exists within - but also maintains - the setting of a balance of power. ${ }^{89}$

After being forced to emigrate to the United States and transitioning from IL to IR in the 1940s, these insights should still be at the heart of Morgenthau's work. Although the focus in later publications gradually shifts away from international law, they still operate within the confines of examining the limits of international law in search for alternative ways to deal with international politics. For one, Morgenthau started to address the failure of the Interwar period. In his view, this was very much due to the depoliticization effect of a 'legalistic approach to foreign policy', which emerged in the second half of the nineteenth century and which presents the 'logical development' of a 'utopian, non-political conception' of foreign policy where it is assumed that international politics is 'an undertaking by peace-loving nations' and where legality is associated with the technocratic rule of legal engineers lacking any capacity for practical judgement. ${ }^{90}$ For another, Morgenthau further elaborated on his concept of politics by tying it closer to the question of power. For him, '[f]oreign policy like all politics, is in its essence a struggle for power, waged by sovereign nations for national advantage'. ${ }^{91}$ This struggle for power is 'universal in time

\footnotetext{
${ }^{83}$ Ibid., at $72,128$.

${ }^{84}$ Ibid., at 71 .

${ }^{85}$ Ibid., at 67; similarly, H. J. Morgenthau, The Concept of the Political (2012), 100-1.

${ }^{86}$ See Morgenthau, supra note 79, at 69; see also Morgenthau, supra note 85.

${ }^{87}$ See Morgenthau, supra note 79, at 145 .

${ }^{88}$ Ibid., at Ch. 16 .

${ }^{89}$ H. J. Morgenthau, Politics Among Nations: The Struggle for Power and Peace (1948), 211. For example, this position resembles Lassa Oppenheim's, who argued that the 'Law of Nations can exist only if there is an equilibrium, a balance of power, between the members of the Family of Nations', L. Oppenheim, International Law (1905), 73. Cf. B. Kingsburry, 'Legal Positivism as Normative Politics: International Society, Balance of Power and Lassa Oppenheim's Positive International Law', (2002) 13 EJIL 401.

${ }^{90} \mathrm{H}$. J. Morgenthau, In Defense of the Natonal Interest: A Critical Examination of American Foreign Policy (1951), 101.

${ }^{91}$ Ibid., at 92 .
} 
and space' as it is part of human nature - a 'desire to dominate, in particular, is a constitutive element of all human associations'. ${ }^{92}$ While the struggle for power can be tamed by law on the domestic level (except for revolutions), this is hardly possible in international politics. Morgenthau's concept of the political thus also presupposes a distinction between the state and the international. In fact, it is because the international is 'politics among nations', i.e., composed of a multiplicity of states, that politics reigns supreme.

As international law and international organizations have limited capacities in settling disputes, Morgenthau increasingly puts his hopes in the role of the prudent statesman and diplomacy, thus largely following Weber's claim that all that tames power politics is an ethics of responsibility. In the end, for Morgenthau, the 'choice is not between legality and illegality but between political wisdom and stupidity', and this choice cannot be made by 'the lawyer but only by the statesman'. ${ }^{93}$ Thus, the state (represented by its leaders and diplomats) remains the main agent of international politics. Within international theory, this theme has been explored and reiterated by various generations of political realists in their conceptualization of the international as characterized by anarchy and the endless repetition of power politics. In such an environment, IL seems to play only a marginal role, although it is worthwhile to keep in mind that Morgenthau's notion of the international thereby also matched a conservative understanding of international law as bound by the will of states.

\subsection{Lauterpacht: Hercules was an international lawyer}

Hersch Lauterpacht ostensibly presents the opposite position, arguing that the nature of the international is ultimately legal. More recently, his position has been characterized as the 'most comprehensive treatment ... to date' of the 'Grotian tradition' in international thought; ${ }^{94}$ and it has been described elsewhere as seminal contribution of the neo-natural law tradition in international legal theory (together with, for example, Alfred Verdross' work). ${ }^{95}$ The notion of 'neo-natural' refers here to two important aspects. Firstly, neo-natural alludes to the fact that Lauterpacht adopted the rigorous scientific method of Kelsen (of whom he was, like Verdross, a student) ${ }^{96}$ but secondly, neo-natural also refers to his refutation of central tenets of the European legal positivist tradition of the time, which had its foundations in formalism, state-centrism, and voluntarism. This goes so far that it appears that Lauterpacht 'wrote all of his work as critique of statehood' and a plea to regard an integrated international community as providing the solution to conflicts between states. ${ }^{97}$ On this basis, Lauterpacht would maintain that the nature of international affairs should be understood as essentially legal.

Lauterpacht refutes legal positivism and political realism basically in three steps, all of them linked to debates over the divides between (international) law and politics. First, in the debate on the non-justiciability of international disputes, Lauterpacht argues in a series of articles during the late 1920s and early 1930s, as well as in his most important monograph, The Function of Law in the International Community (published in 1933), that all disputes could ultimately be legally

\footnotetext{
${ }^{92}$ See Morgenthau, supra note 89, 17.

${ }^{93}$ H. J. Morgenthau, 'Diplomacy', (1946) 55 The Yale Law Journal 1067, at 1080.

${ }^{94} \mathrm{R}$. Jeffery, 'Hersch Lauterpacht, the Realist Challenge and the "Grotian Tradition" in 20th-Century International Relations', (2006) 12 European Journal of International Relations 223, at 225; see also Lauterpacht's own essay on this tradition, H. Lauterpacht, 'The Grotian Tradition of International Law', (1946) 23 BYIL 1. For recent reflection on this tradition see M. Koskenniemi, 'Imagining the Rule of Law: Rereading the Grotian “Tradition”, (2019) 30 EJIL 17.

${ }^{95}$ For further discussion of the different streams of the natural law tradition in international legal theory see G. Gordon, 'Natural Law in International Legal Theory: Linear and Dialectic Presentations', in Orford and Hoffmann, supra note 8, 279, at 292-3. Or, as Scobbie puts it: 'A natural law thesis, albeit initially inarticulate, is the thread which runs through and unifies Lauterpacht's work', I. G. M. Scobbie, 'The Theorist as Judge: Hersch Lauterpacht's Concept of the International Judicial Function', (1997) 8 EJIL 264, at 266.

${ }^{96}$ Similarly: 'Lauterpacht's theoretical construction of international law is rooted in Kelsenite legal epistemology', see Scobbie, ibid., at 265.

${ }^{97}$ See Koskenniemi, supra note 5 , at 8 .
} 
resolved. ${ }^{98}$ Perhaps surprisingly, Lauterpacht agrees with Morgenthau that it is impossible to draw a line distinguishing between the legal and political nature of disputes on the international level. As he writes, the same 'dispute may be purely legal and purely political, i.e., it may be capable of legal decision so as to admit of a judicial settlement and it may be regarded as "important" so as to make arbitration appear dangerous.$^{99}$ However, Lauterpacht comes to a completely different conclusion, as for him 'all international disputes are, despite of their gravity, disputes of legal character in the sense that, so long as the rule of law is recognized, they are capable of an answer by application of legal rules'. ${ }^{100}$ For Lauterpacht, this premise of the legal nature of all international disputes has important consequences for it implies and invokes the completeness of international law, which 'is an a priori assumption of every system of law, not a prescription of positive law'. ${ }^{101}$ Even if states refuse following international law as they see their 'vital interest' or 'honour' at stake, law is for Lauterpacht counterfactually valid and the last word remains with the international judge. As Lauterpacht writes in a generally positive review of Morgenthau's second book on The Concept of the Political:

The reader will easily agree with Dr. Morgenthau's emphasis on the sociological value of the distinction between juridical and political disputes. What is less clear is its legal value, namely, its usefulness in treaties of obligatory settlement of international disputes. ${ }^{102}$

Second, it follows from the supposed completeness of international law that the task of the international lawyer as judge and arbitrator - the judicial function - is to guarantee through progressive interpretation the completeness of international law. Koskenniemi has summarized Lauterpacht's position in the following terms:

Contrary to Kelsen, Lauterpacht does not postulate formal but material completeness of law, constructed by the lawyer as he proceeds to solve the case ... For Lauterpacht, legal problem-solution seeks to ensure the unity, consistency and effectiveness of international law as a whole. By using analogy and abstracting principles from individual rules the lawyer will be able to perceive the law as a coherent, meaningful whole which "is originally and ultimately not so much a body of legal rules as a body of legal principles". These principles express the law's autonomous, systemic "coherence" which ultimately justifies the solution of hard cases. ${ }^{103}$

The claim of the completeness of international law signifies for Lauterpacht that the legal system has no gaps (lacunae) and that an international court cannot declare that there is no applicable law (non liquet) and that it has, consequently, no jurisdiction over a specific case. ${ }^{104}$ It is up to the judicial function to fill gaps and to make every case justiciable by recourse to analogies from

\footnotetext{
${ }^{98}$ H. Lauterpacht, 'The Doctrine of Non-Justiciable Disputes in International Law', (1928) 24 Economica 277; H. Lauterpacht, The Function of Law in the International Community (2011).

${ }^{99}$ See Lauterpacht, ibid. (1928), at 299.

${ }^{100}$ See Lauterpacht, supra note 98 (2011), at 166 (emphasis added); on differences and similarities between Lauterpacht and Morgenthau see M. Koskenniemi, 'The Function of Law in the International Community: Introduction', in ibid., xxix, at xxxvi-xlii.

${ }^{101}$ See Lauterpacht, ibid., at 72.

${ }^{102}$ H. Lauterpacht, 'Review: Morgenthau, Hans, La Notion du "Politique” et la théorie des différends internationaux', (1934) 3 Zeitschrift für Sozialforschung 461, at 461.

${ }^{103}$ See Koskenniemi, supra note 3, at 53; on Lauterpacht and the completeness of the legal system see Koskenniemi, supra note 23 , at 361-9.

${ }^{104}$ As Lauterpacht states, 'the prohibition of non-liquet is one of the general principles of law recognised by civilised nations', Lauterpacht, supra note 98 (2011), at 75. See also Lauterpacht's later publication on this topic, H. Lauterpacht, 'Some Observations on the Prohibition of "Non Liquet" and the Completeness of the Legal Order', in J. H. W. Verzijl (ed.), Symbolae Verzijl: Présentées au Professeur J.H.W. Verzijl à l'occasion de son LXXX-Ième anniversaire (1958), 196.
} 
municipal and private law, general principles or the moral purpose of international law. ${ }^{105}$ That a judge or arbitrator has to fulfil this function is, at first glance, nothing specific to international law. In every legal order abstract norms need to be applied to concrete cases as they cannot specify and anticipate all conditions of their application. However, the image of the international judge as "'Herculean" gap-filler"106 in combination with the prohibition of non liquet has far-reaching consequences as it extends, at least potentially, the jurisdiction of international courts ad infinitum. It was, as Koskenniemi notes, also a 'subtle ("hegemonic") manoeuvre to embolden those (judicial) institutions whose biases he shared to declare them as universal preferences'. ${ }^{107}$ Lauterpacht's approach is also a hegemonic move with regard to the question of how international disputes should be solved - not through politics and diplomacy, as suggested by Morgenthau, but by law and courts. To put it differently, the final say, competence, and expertise in world politics would not lie with diplomats, but with judges.

Third, Lauterpacht rejects the view that international law is limited to the will of states. ${ }^{108}$ Instead, in The Function of Law in the International Community he argues that international law's voluntarism is not per se limited to obligations between states, as states could - Lauterpacht deliberately uses the conjunctive form - also be bound to the will of the international community (voluntas civitatis maximae est servanda). As Lauterpacht stresses in an often-quoted passage:

There is no reason why the original hypothesis in international law should not be that the will of the international community must be obeyed ... An initial hypothesis expressed in the terms of voluntas civitatis maximae est servanda would point, as the source of law, to the will of the international society expressing itself in contractual agreements between its constituent members, in their customs, and in the general principles of law which no civilized community can afford to ignore; it would refer to the civitas maxima as meaning that super-State of law which States, through the recognition of the binding force of international law qua law, have already recognized as existing over and above national sovereignties. ${ }^{109}$

Thus, Lauterpacht ties international law to the principle of the 'will of the international community' and thereby seeks to leave behind an image of the international as dominated by states. In Lauterpacht's later work, the 'will of the international community' as the foundation of the international legal order should become eventually substituted by the individual. Although Lauterpacht beliefs, in contrast to Morgenthau's pessimistic anthropology, that the 'nature of man' is 'intrinsically moved by a desire for social life, endowed with an ample measure of goodness, altruism, and morality', ${ }^{110}$ he does not justify the central role of the individual purely anthropologically but also by arguing that:

behind the mystical, impersonal, and therefore necessarily irresponsible personality of the metaphysical state there are actual subjects of rights and duties, namely, individual human beings ... The individual is the ultimate unit of all law, international and municipal, in the double sense that the obligations of international law are ultimately addressed to him and

\footnotetext{
${ }^{105}$ That Lauterpacht highlights inter alia the role of analogies from private law is hardly surprising. His doctoral thesis was a study of private law analogies in international law. In this thesis, Lauterpacht refutes the prevailing positivist view that international law is a 'form of general jurisprudence' and argues, instead, that it resembles more private law as both international law and private law are governing the relations between equals, Hersch Lauterpacht, Private Law Analogies in International Law with Special Reference to International Arbitration (1926), at 69.

${ }^{106}$ See Koskenniemi, supra note 100, at xliii. For a discussion of the similarities between Lauterpacht and Ronald Dworkin's image of the judge see Koskenniemi, supra note 3, at 53-8.

${ }^{107}$ See Koskenniemi, supra note 3, at 609.

${ }^{108}$ See Lauterpacht, supra note 98 (2011), at 427.

${ }^{109}$ Ibid., at 429-30.

${ }^{110}$ See Lauterpacht, supra note 94, at 24.
} 
that the development, the well-being, and the dignity of the individual human being are a matter of direct concern to international law. ${ }^{111}$

Thus, Lauterpacht furnished a radical view of the international as an ultimately legal sphere. Yet, by relying on such a far-reaching notion of the judicial function, he silently re-introduced a certain form of politics. Politics, here, is not the kind of power politics between states, which is forged and regulated by diplomats, as in Morgenthau, but it is the progressive extension of the legal sphere by courts and judges operating as representatives of the international community and pursuing a politics of universalism and humanity.

\section{Interdisciplinary circles: State creation and the judicial function today}

If the intellectual confrontations between Weber and Kelsen and between Morgenthau and Lauterpacht help reconstructing historical differentiations and intimate connections between legality and politics along the divide of the domestic and the international, this section illustrates their lasting impact by way of discussing two areas of contention as examples. We first sketch current debates about state creation and recognition between IL and IR, and the limits of legal and political reductions within them, before turning to the legal and political evaluation of the judicial function - and its political side - in current international jurisprudence and arbitration. We link in both instances particular challenges of international law and politics in practice with their (inter)disciplinary interpretation, thus showing how the basic matrix of two lines shapes the apparent stakes and limits of (inter)disciplinary discussions over important issues of contention in (international) law and politics today.

\subsection{The spectre of the other: Current debates over the state between IL and IR}

Kelsen's attempt to fend off both the notion that states emerged as a matter of fact alone and the politics of discretionary recognition by third states points to a persistent tension in the international law of state creation. This tension has classically been expressed before and beyond Kelsen in the so-called 'great debate' between the constitutive and the declaratory doctrine of recognition. ${ }^{12}$ Whereas for the former states become persons of international law upon formal recognition only, ${ }^{113}$ according to the latter recognition takes merely note of new states whose legal status follows directly from their factual emergence. ${ }^{114}$ Both positions presented themselves as the respective legal view, and rejected the other as political. For a proponent of the declarative position, the constitutive view suits the interests of 'Machiavellian statesmen' because it 'provides them with a justification for ignoring the existence of other entities and denying them rights under international law'. ${ }^{115}$ By contrast, from the constitutive view of recognition, letting facts speak for themselves violates basic principles of legal positivism and interpretation, and notably ignores that in practice recognition determined new states as subjects of international law. ${ }^{116}$ Both views are somewhat discredited today, ${ }^{117}$ neither seems to safeguard a genuinely legal assessment of state creation. The double rejection of the reduction of states to either facts or political decisions - so crucial for Kelsen - is thus also apparent in the twentieth century development of the international law of state creation, which has sought to explicitly base evaluations of state creation on rights and

\footnotetext{
${ }^{111}$ Ibid., at 27.

${ }^{112}$ See Crawford, supra note 72, at 19-28; T. D. Grant, The Recognition of States: Law and Practice in Debate and Evolution (1999).

${ }^{113}$ See Oppenheim, supra note 89 , at 110.

${ }^{114}$ See Chen, supra note 72.

${ }^{115}$ Ibid., at 4 .

${ }^{116}$ See Crawford, supra note 72 , at 5, 17; Kelsen, supra note 67.

${ }^{117}$ The classical constitutive position is now largely regarded as 'unacceptable' (Crawford, ibid., at 27), while the declarative position is often endorsed in principle (ibid., at 28). However, given both the role of recognition in practice and the consideration of other legal principles of statehood than 'effectiveness', it appears that 'neither theory of recognition satisfactorily explains modern practice' (ibid., at 5).
} 
rules, including the self-determination of peoples, territorial integrity, and the general prohibition of the use of force. ${ }^{118}$ Rather than taken to emerge before or outside of international law, state creation was firmly integrated into international law. This does not mean that the state itself lost significance or appeal, however. To the contrary, it was independent statehood which anticolonial liberation movements were struggling for. Decolonization promised emancipation not because it overcame statehood and sovereignty as attributes of an old international legal order, but because it delivered them to political communities in the Global South. ${ }^{119}$ As the recent Advisory Opinion of the International Court of Justice (ICJ) in Legal Consequences of the Separation of the Chagos Archipelago from Mauritius in 1965 illustrates, self-determination and - unfinished - decolonization still play a central role in disputes over territories and the jurisdiction of states. ${ }^{120}$

The spectre of power politics, it might seem, has thus been pushed to the very margins of IL since the resort to either effectiveness or recognition alone seems no longer acceptable. Cases of contested state creation suggest that this is not the case, however. In fact, since legal rights and prohibitions alone are insufficient to identify individual states, they are often invoked in various combinations with classical arguments about state recognition and effectiveness to bolster one position as legal while condemning another as political. ${ }^{121}$ For instance, some argue that Palestine is legally a state by virtue of its right to self-determination and history as Class ' $A$ ' Mandate under the League of Nations, its declarations of independence, its recognition by many other states, and its status as 'non-member observer state' granted by the UN General Assembly. ${ }^{122}$ From this perspective, the neglect of its legal state status must appear as a political move to deny it particular rights, including its request that the International Criminal Court (ICC) investigates alleged crimes committed on Palestinian territory. ${ }^{123}$ However, others argue that because of its lack of universal recognition, as well as its compromised effectiveness and independence, Palestine is not - yet - a state. ${ }^{124}$ From this angle, assuming that Palestine is already a state should be regarded as a political rather than a proper legal position.

Similarly, both the decision of a number of states to recognize Kosovo upon the controversial 2008 declaration of independence and the 2010 Advisory Opinion by the ICJ have led IL scholars to emphasize the apparent limits of law, and the role power politics play in cases of state creation. ${ }^{125}$ Indeed, the partial recognition of Kosovo was infamously followed by the Russian recognition of Abkhazia and South Ossetia, although this move has been widely rejected. Conversely, supposedly effective but unrecognized entities such as Somaliland led some legal scholars to argue that they were essentially states under international law, and should be recognized as such, ${ }^{126}$ while others deny this. ${ }^{127}$ Thus, the evolution of international law notwithstanding, attempts

\footnotetext{
${ }^{118}$ See Crawford, supra note 72; see also M. G. Kohen (ed.), Secession: International Law Perspectives (2004); D. French (ed.), Statehood and Self-Determination in International Law (2013).

${ }^{119}$ S. Moyn, 'The High Tide of Anticolonial Legalism', (2021) 23 Journal of the History of International Law/Revue d'histoire du droit international 5.

${ }^{120}$ Legal Consequences of the Separation of the Chagos Archipelago from Mauritius in 1965, Advisory Opinion of 25 February 2019, [2019] ICJ Rep. 95.

${ }^{121}$ See N. Berman, 'Sovereignty in Abeyance: Self-determination and International Law', (1988) 7 Wis. Int'l LJ 7, 51; Koskenniemi, supra note 3, at 272-82.

${ }^{122}$ J. Quigley 'Palestine is a State: A Horse with Black and White Stripes is a Zebra', (2010) 32 Mich. J. Int'l L. 749; J. Quigley, 'Palestine Statehood and International Law', Global Policy Essay (2013), 1.

${ }^{123}$ State of Palestine, Preliminary examination, ICC, available at www.icc-cpi.int/palestine.

${ }^{124}$ See Crawford, supra note 72, at 442-8; R. W. Ash, 'Is Palestine a State: A Response to Professor John Quigley's Article, "The Palestine Declaration to the International Criminal Court: The Statehood Issue", (2009) 36 Rutgers L. Rec. 186.

${ }^{125} \mathrm{~J}$. Almqvist, 'The Politics of Recognition: The Question about the Final Status of Kosovo', in D. French (ed.), Statehood and Self-Determination in International Law (2013), 165; A. X. M. Ntovas, 'The Paradox of Kosovo's Parallel Legal Orders in the Reasoning of the Court's Advisory Opinion', in French, ibid., at 139.

${ }^{126}$ A. K. Eggers, 'When is a State a State-The Case for Recognition of Somaliland', (2007) 30 BC Int'l \& Comp. L. Rev. 211; J. N. Maogoto, 'Somaliland: Scrambled by International Law?', in French, ibid., at 208.

${ }^{127}$ See Crawford, supra note 72 , at $415,417$.
} 
to grasp state creation as a legal phenomenon regularly cross into politics, whether in terms of effective statehood on the ground or recognition by third states. Politics are invoked not only to reject an opposing position as non-legal, but also to simultaneously build on effectiveness and recognition as a factual basis for law. ${ }^{128}$

Meanwhile, IR approaches to the emergence of states struggle as much to liberate themselves from recourse to legality as IL perspectives seek to banish the resort to politics. This can be illustrated by a glance at two IR literatures that have gained traction in the last decade, one concerned with practices of recognition in international politics, ${ }^{129}$ the other with the emergence and position of supposed de facto or unrecognized states. ${ }^{130}$ In studies of state recognition, the analysis focuses on practices of recognition and their causes, ${ }^{131}$ and it is often accompanied by a rejection of distinctly legal perspectives. ${ }^{132}$ Although the dynamics of recognition are complex, a particularly important role is accorded to the political interests of great powers, a nod towards Morgenthau's understanding of international politics. In this view, the recognition of separatists in the former Yugoslavia, such as Croatia, and the non-recognition of autonomous regions in Soviet republics, such as Chechnya, are a function of international politics, not law. ${ }^{133}$ However, the frequent resort to an international law definition of statehood, the very belief that formal recognition creates states, and the finding that normative considerations influence recognition all point to the relevance of international law as the very vocabulary in which arguments about practices of recognition are nested.

Meanwhile, the literature on de facto states borrows from Weber's notion of the state and argues that despite the lack of legal recognition, entities such as Transnistria or Somaliland are effectively states. ${ }^{134}$ However, in order to distinguish de facto states from potent rebel groups or warlords, scholars often seek to measure statehood according to the famous Montevideo criteria. ${ }^{135}$ Although the concrete measurements are much debated, ${ }^{136}$ they indicate that IR scholars curiously turn to international law in their search for proper criteria of state creation. Moreover, despite the claim that state creation is essentially a process of acquiring territorial control, the often dire and dangerous situation of de facto states also seems to suggest that recognition matters after all, since it evidently endows states with rights and obligations, and provides access to international organizations. ${ }^{137}$ Ultimately, then, legality re-enters the stage to help determine states beyond varying degrees of effectiveness.

Thus, although perspectives on state creation in IL and IR take opposite vantage points, they both struggle to identify individual states that seem to exceed their grasp. What determines states is constantly played back between politics and law, facts and norms. The underlying, shared assumption animating this game is that individual states do exist and must be identified as components of the international realm. ${ }^{138}$ The nested oppositions between (international) law and politics have thus set up a matrix within which the creation of new states can be justified and

\footnotetext{
${ }^{128}$ J. Grzybowski, 'To Be or Not to Be: The Ontological Predicament of State Creation in International Law', (2017) 28 EJIL 409.

${ }^{129}$ M. Fabry, Recognizing States: International Society and the Establishment of New States since 1776 (2010); B. Coggins, Power Politics and State Formation in the Twentieth Century: The Dynamics of Recognition (2014); R. D. Griffiths, Age of Secession: The International and Domestic Determinants of State Birth (2016).

${ }^{130}$ S. Pegg, International Society and the De Facto State (1998); D. Geldenhuys, Contested States in World Politics (2009);

N. Caspersen, Unrecognized States. The Struggle for Sovereignty in the Modern International System (2012).

${ }^{131}$ See Fabry, supra note 129; Coggins, supra note 129; Griffiths, supra note 129.

${ }^{132}$ See Fabry, ibid., at 5; Coggins, ibid., at $28-32$.

${ }^{133}$ See Coggins, ibid.

${ }^{134}$ See Pegg, supra note 130; Geldenhuys, supra note 130; Caspersen, supra note 130.

${ }^{135}$ See Pegg, ibid., at 27; Geldenhuys, ibid., at 8; Caspersen, ibid., at 17.

${ }^{136}$ Ibid.

${ }^{137}$ See Caspersen, ibid.

${ }^{138}$ J. Grzybowski, 'The Paradox of State Identification: De Facto States, Recognition, and the (Re-)Production of the International', (2019) 11 International Theory 241.
} 
contested in various ways, but which beyond all concrete disputes has itself become invisible as their very condition of possibility.

\subsection{The judicial function today}

While both Morgenthau and Lauterpacht refuse a simplistic dichotomy between law and politics, they nevertheless develop opposing arguments about the nature of the international: Morgenthau emphasizes that in principle the international is a sphere of power politics with little room for international law, whereas Lauterpacht argues that international law is materially closed, due to objective normativity, and that every dispute can thus be subsumed under it. The debate over the relationship between international law and politics continued after the Second World War, in particular in the context of the judicial activity of the ICJ. For example, Rosalyn Higgins observed in 1968 that British and American international lawyers conceptualized the relationship between law and politics in entirely different ways. ${ }^{139}$ While the former favoured a rule-based and static notion of international law, with a separation of law and politics and a 'conservative' approach by the Court to the judicial function, the American policy-oriented approach would conceive of international law as a dynamic process, in which a clear distinction between law and politics was not feasible and 'judicial creativity' appeared as positive and - on the international level necessary feature of the legal process. ${ }^{140}$ At the same time:

whilst [the Court] recogniz[ed] the distinction between legal and political aspects of a dispute, it has consistently rejected the claim that the intermixture of legal and political issues was a sufficient ground to refuse to consider the legal issues in themselves. ${ }^{141}$

However, by interpreting, for instance, the principles of stare decisis or ex aequo et bono in a reluctant way, the Court manifested a 'tendency to choose judicial restraint over judicial activism'. ${ }^{142}$

Recent decades have seen a renegotiation of the relationship between law and politics, with the proliferation of various courts and tribunals after the Cold War as a key driver. In academic circles, the development has been debated in terms of the legalization of world politics and, later, the politicization of international law. Within IR, for example, the role of the judicial function, and the question of the (non)justiciability of international disputes, have received a good deal of attention in scholarship on the 'judicialization' of international politics understood as 'the process by which courts and judges increasingly dominate politics and policy-making' and which 'at the international level ... can diminish the sovereignty of states and the autonomy of leaders'. ${ }^{143}$ This literature seeks to leave behind the classical assumption that 'legalized domestic politics must be fundamentally different from legalized international politics'. ${ }^{144}$ Other voices, however, have criticized the idea of an almost linear process of judicialization on the international level by pointing to recent 'backlashes' for various courts, which might even lead to the reverse process of 'dejudicalization' and the 'reacquisition of power by executives and legislatures'. ${ }^{145}$ Yet, what unites

\footnotetext{
${ }^{139}$ R. Higgins, 'Policy Considerations and the International Judicial Process', (1968) 18 ICLQ 58; see also R. Higgins, 'Diverging Anglo-American Attitudes to International Law', (1972) 2 Georgia Journal of International and Comparative Law 1.

${ }^{140}$ See Higgins, ibid. (1968), at 68, 69.

${ }^{141}$ G. I. Hernández, The International Court of Justice and the Judicial Function (2014), 70.

${ }^{142}$ D. Mawar, 'The Perils of Judicial Restraint: How Judicial Activism Can Help Evolve the International Court of Justice', (2019) 9 Goettingen Journal of International Law 425, at 436.

${ }^{143}$ See Alter, Hafner-Burton and Helfer, supra note 2, at 449; for further discussion see also G. I. Hernández, 'The Judicialization of International Law: Reflections on the Empirical Turn', (2014) 25 EJIL 919. This resembles earlier debates on the 'legalization of world politics', see Abbott et al., supra note 2.

${ }^{144}$ See Alter, Hafner-Burton and Helfer, ibid., at 450.

${ }^{145}$ See Abebe and Ginsburg, supra note 6, at 521.
} 
both camps is that Morgenthau's paradigmatic tenet, i.e., that some conflicts in international politics are not justiciable, has become a testing ground for empirically-oriented social sciences using the vocabulary of delegation, authority, legitimacy, and effectiveness. ${ }^{146}$

Within international legal practice, the rise of international courts and tribunals equally touches upon the relationships between legality and politics and between the state and the international, in particular in international criminal law. Here, the Tadic decision of the Appeals Chamber of the International Criminal Tribunal for the former Yugoslavia (ICTY), as the first decision by an international criminal body since the post-Second World War trials and tribunals, stands out as a particularly illustrative case in point. ${ }^{147}$ The main task of the Chamber was to decide whether the ICTY actually has, as an international tribunal established by the UN Security Council, jurisdiction over international crimes that were committed during the Yugoslav Wars. The simplest and less contested strategy for the Chamber would have been to declare the conflict an international conflict with the consequence that crimes committed during the Yugoslav Wars fall under the jurisdiction of the ICTY. The Chamber, however, opted for another avenue: it determined that although the Yugoslav Wars were a non-international armed conflict, the ICTY still had jurisdiction over it, arguing that particular rules of international humanitarian law had become customary international law that is applicable to non-international conflicts too. ${ }^{148}$

To substantiate this point, the Chamber distinguished between a traditional and a modern notion of international law. The former relied on a 'dichotomy' between the domestic and the international and 'was clearly sovereignty-oriented and reflected the traditional configuration of the international community, based on the coexistence of sovereign States more inclined to look after their own interests than community concerns or humanitarian demands'. ${ }^{149}$ In this setting, there were few international rules for internal conflicts. Not so in 'modern' international law. In a passage, which could have been drafted by Lauterpacht, the Chamber sketches the emergence of a modern notion of international law, where a 'State-sovereignty-oriented approach have [sic] been gradually supplanted by a human-being-oriented approach' and where '[g]radually the maxim of Roman law hominum causa omne jus constitutum est (all law is created for the benefit of human beings) has gained a firm foothold in the international community as well'. As a consequence of this development:

the distinction between interstate wars and civil wars is losing its value ... If international law, while of course duly safeguarding the legitimate interests of States, must gradually turn to the protection of human beings, it is only natural that the aforementioned dichotomy should gradually lose its weight. ${ }^{150}$

The Tribunal came to this conclusion by a rather novel way of (progressively) interpreting customary international law, namely by, on the one hand, finding a precedent of modern international law since the Interwar period (in particular the Spanish Civil War) ${ }^{151}$ and, on the other hand, foregrounding the subjective element of opinio juris and not only relying on its objective element (state practice). ${ }^{152}$ Unsurprisingly, the Tadić decision did not remain uncontested. While supporters of the decision argued that it is the task of the judicial function to find the applicable

\footnotetext{
${ }^{146}$ See, for example, Abbott et al., supra note 2; Zürn, Binder and Ecker-Ehrhardt, supra note 2; Dunoff and Pollack, supra note 9.

${ }^{147}$ Prosecutor v. Tadić, Decision on the Defence Interlocutory Appeal on Jurisdiction, Case No. IT-94-1-AR72, Appeals Chamber, 2 October 1995.

${ }^{148}$ Ibid., para. 127; see, in general, ibid., paras. 96-127.

${ }^{149}$ Ibid., para. 96

${ }^{150}$ Ibid., para. 97.

${ }^{151}$ Ibid., para. 97

${ }^{152}$ Ibid., para. 99.
} 
law, its critics brought forward that the Tribunal might have engaged in judicial activism, i.e., 'overstretching' the law and thereby using it for political purposes. ${ }^{153}$

More recently, the question of the justiciability of international disputes has been brought up in the context of the ICC decision to open an investigation into international crimes committed in Afghanistan between 2003 and 2014. In 2017, the Prosecutor filed a request to open such an investigation against the Taliban, the Afghan National Security Forces, and the United States and its CIA. ${ }^{154}$ Two years later, the Pre-Trial Chamber (PTC) rejected the request by concluding that 'notwithstanding the fact that all the relevant requirements are met as regards both jurisdiction and admissibility, an investigation into the situation in Afghanistan would not serve the interests of justice' ${ }^{155}$ The PTC arrived at this decision by arguing, inter alia, that the justiciability of the conflict is not guaranteed due to political reasons as 'changes within the political landscape both in Afghanistan and in key States (both parties and non-parties of the Statute), coupled with the complex volatility of the political climate still surrounding the Afghan scenario' make it likely that the investigation would ultimately remain inconclusive and bind too many resources of the Court. ${ }^{156}$ The decision was criticized by many observers who argued that the PTC went ultra vires by interpreting the notion of 'interest of justice' in such a way. In March 2020, the ICC Appeals Chamber reversed the decision of the lower chamber as the PTC 'did not properly assess the interest of justice' and therefore allowed investigations into the alleged international crimes in Afghanistan. ${ }^{157}$

Both the Tadic decision and the controversy about the investigation in Afghanistan illustrate the contested nature of the boundary between the domestic and the international, and in both cases decisions were criticized as violating the boundary between law and politics. However, the respective criticisms aimed into opposite directions. While the Tadić decision of the ICTY was regarded as political because it assumed the justiciability of internal conflicts under international law, the PTC was criticized for refusing to open an investigation on grounds of considering it non-justiciable. As such, both examples reflect the debate over whether the international is a political or a legal sphere, and illustrate that while the answers to this question fluctuate, the contested divide itself remains the basis for current arguments and counter-arguments about the judicial function.

\section{Conclusion}

The matrix of (international) politics and law has been established by fostering, probing, and renewing their conceptual boundaries and argumentative circuits, as in the two paradigmatic debates reconstructed in this article. The reductions of the state and the international to politics and legality pursued by Weber and Kelsen and by Morgenthau and Lauterpacht have pushed the boundaries of their respective vantage points, but they thereby also entangled them. As we have further illustrated, within debates over state creation and international justiciability, the

${ }^{153}$ Cf. J. E. Alvarez, 'Nuremberg Revisited: The Tadic Case', (1996) 7 EJIL 245; for a general discussion on 'judicial activism' see F. Zarbiyev, 'Judicial Activism in International Law - A Conceptual Framework for Analysis', (2012) 3 Journal of International Dispute Settlement 247.

${ }^{154}$ The investigation's opening can also be understood as a reaction of the ICC towards criticism that depicted the Court as a 'European Court of African Affairs' due to the selection of cases and as it reflects a European project - both in its intellectual and political origins. For further discussion see S. Nouwen, 'The International Criminal Court: A Peacebuilder in Africa?', in D. Curtis and G. A. Dzinesa (eds.), Peacebuilding, Power, and Politics in Africa (2012), 171. In this context, the Office of the Prosecutor (OPT) (re)opened investigations into alleged British war crimes during the Iraq War. However, on 9 December 2020, the OTP decided to not further investigate due to the principle of complementarity as it found that the United Kingdom had taken genuine action to investigate the crimes in the meantime.

${ }^{155}$ Situation in the Islamic Republic of Afghanistan, Decision on the Authorisation of an Investigation into the Situation in the Islamic Republic of Afghanistan, Case No. ICC-02/17, Pre-Trial Chamber II, 12 April 2019, para. 96

${ }^{156}$ Ibid., para 94.

${ }^{157}$ Situation in the Islamic Republic of Afghanistan, Judgment on the Appeal against the Decision on the Authorisation of an Investigation into the Situation in the Islamic Republic of Afghanistan, Case No. ICC-02/17 OA4, Appeals Chamber, 5 March 2020, para. 50 . 
distinctions between legality and politics and between the domestic and the international continue to shift and blur. States appear variably as legal or political entities, as domestically or internationally constituted, while the justiciability of international crimes in armed conflicts is variably expanded and rejected as 'political'. Yet, the distinctions themselves remain and thereby constrain the debates. Legality and politics cannot be entirely separated, but they cannot be fully merged either, providing important insights into the dynamics, effects, and blind spots of the differentiation between the disciplinary perspectives, and their shared relationship with the equally constitutive divide between states and the international. As the stability of the matrix is paradoxically achieved through the instability of its categories, this tension also creates space for projects of critique and emancipation within the matrix, while at the same time limiting their scope.

To be sure, our own reconstruction of 'paradigmatic' interdisciplinary debates has focused on what appears to be central, continuous, and necessary in the relationship between (international) politics and legality beyond all contestations and blurring, thereby highlighting processes of reification. A different reconstruction could instead bring to the fore what was contingent in the emergence of these relationships themselves, what escaped the grip of their categories, and what promises radical change. ${ }^{158}$ Indeed, it is no accident that both critical IL and IR have recently taken a 'historical turn', and that this turn has spawned stories of contingency and restriction alike. While some argue that only a 'radical historical critique' beyond dominant 'markers, periodisation and causal sequencing' can help us escape the conceptual circuits of the established disciplinary imagination, ${ }^{159}$ others maintain that critical legal analysis must be accompanied by 'socio-historical structuralism' to seriously consider the material conditions under which international law operates. ${ }^{160}$ Both the call for appreciating the contingency of history and historiography and the turn to wider social structures can help illuminate Eurocentric blind spots and hierarchies of international law, inject new lines of critique, and imagine alternatives. While it currently remains difficult to imagine that alternative narratives would not have to grapple with the deeply entrenched boundaries of (international) politics and legality as conceptual matrix, the contingency of these boundaries themselves might become readily apparent in the wake of significant events, developments, and changes of perspective that would encourage a different understanding of history, and as such 'reveal' that it has always already pointed elsewhere. ${ }^{161}$

However, this article also alludes to current limits to removing the boundaries of our interdisciplinary imagination. International law in its dominant conceptualization is constituted by its difference to other social and intellectual spheres - including notably politics, but also economy, religion, and others - and thus cannot be overturned without questioning those basic boundaries of modern society as well. ${ }^{162}$ Indeed, the matrix of international law and politics precisely

\footnotetext{
${ }^{158}$ On the possibility of alternative readings see R. K. Ashley, 'Untying the Sovereign State: A Double Reading of the Anarchy Problematique', (1988) 17 Millennium - Journal of International Studies 227.

${ }^{159}$ J. d'Aspremont, 'Critical Histories of International Law and the Repression of Disciplinary Imagination', (2019) 7 London Review of International Law 87, at 92; see d'Aspremont, supra note 24. For IR see Z. G. Çapan, 'Beyond Visible Entanglements: Connected Histories of the International', (2020) 22 International Studies Review 289.

${ }^{160}$ J. D. Haskell, 'TRAIL-ing TWAIL: Arguments and Blind Spots in Third World Approaches to International Law', (2014) 27 Canadian Journal of Law and Jurisprudence 383.

${ }^{161}$ On events see F. Johns, R. Joyce and S. Pahuya (eds.), Events: The Force of International Law (2011); see also J. Derrida, 'A Certain Impossible Possibility of Saying the Event', (2007) 33 Critical Inquiry 441.

${ }^{162}$ N. Luhmann, Social Systems (1995); for a problematization of public international law's state-centrism by excluding categories from private law such as property see M. Koskenniemi, 'Expanding Histories of International Law', (2016) 56 American Journal of Legal History 104; on the concept of development see S. Pahuja, Decolonising International Law: Development, Economic Growth and The Politics of Universality (2011); on the consequences of excluding religion see M. Koskenniemi, M. Garia-Salmones Rovira and P. Amorosa (eds.), International Law and Religion: Historical and Contemporary Perspectives (2017).
} 
points to the resilience, if also the flexibility, of these boundaries. ${ }^{163}$ Moreover, the basic concepts and nested oppositions of (international) law and politics are also resilient because they offer orientation and inspiration in practice, that is, for articulating positions and counter-positions when making 'legal' cases, and rejecting 'politics', or, conversely, rejecting 'legal' technique in favour of authentic 'politics'. As such, the matrix is constantly reloaded, not only in scholarship, but also in everyday international affairs. If it must be actively enacted, however, there is also space for exploring the different ways in which it has fostered domination, enabled resistance, and continues to generate possibilities for transformation within and across the boundaries of international law and politics.

\footnotetext{
${ }^{163}$ For example, the debate over the appropriate use of context in international legal histories has recently led to a juxtaposition of a 'historiographical' and a 'juridical' notion of context. While '[t]he self-imposed task of today's contextualist historians is to think about concepts in their proper time and place', 'the task of international lawyers is to think about how concepts move across time and space'; see A. Orford, 'The Past as Law or History? The Relevance of Imperialism for Modern International Law', (2012) NYU IILJ Working Paper 2, at 2; see also M. Arvidsson and M. Bak McKenna, 'The turn to history in international law and the sources doctrine: Critical approaches and methodological imaginaries', (2020) 33 LJIL 37, at 47-51. This resembles, to a certain degree, earlier attempts at disciplinary closure: see Klabbers, supra note 5; Koskenniemi, supra note 5; Rajkovic, supra note 5.
}

Cite this article: dos Reis F and Grzybowski J (2021). The matrix reloaded: Reconstructing the boundaries between (international) law and politics. Leiden Journal of International Law 34, 547-570. https://doi.org/10.1017/S0922156521000200 